\title{
O esporte como fator de desenvolvimento e de saúde mental na criança e no adolescente
}

\author{
Eronides Borges da Fonseca
}

Concomitantemente ao desenvolvimento somático efetuase o psicológico, havendo sempre uma interação entre ambos. Imaginemos uma criança ao nascer, com instintos que a farão lutar pela sobrevivência. Diferente de outros animais, o ser humano é completamente dependente ao nascimento. É a fome, a sede, o choro, o desespero que chamam a atenção do ambiente (mãe) para alimentá-la, aquecê-la, confortá-la para que possa sobreviver. Imaginemos também que essa criança não seja somente um ser instintivo, que já possua um Ego incipiente, isto é, uma parte de si mesma que interage ao mesmo tempo com seus instintos e com o meio que a cerca, de forma inconsciente.

Isso, que até há pouco tempo parecia ficção ou fantasia de algum psicanalista visionário, tornou-se realidade comprovada nos estudos e pesquisas com o método da ultra-sonografia. Os fetos reagem, mudam de posição, acalmam-se, agitam-se, sugam o dedo, entre outras coisas, com a luz, o som, vozes, música, etc.

Esse Ego está sempre em contato com o corpo e suas necessidades. O exercício físico que contribui para o desenvolvimento corporal também o faz para o Ego, isto é, crescimento físico e mental.

A partir de certa idade, digamos, entre três e cinco anos, forma-se outra estrutura mental, que chamamos de Superego. Sempre que falamos de Superego pensamos em censura, castigo, culpa, etc. Todavia, não podemos esquecer de que o Superego é depositário também dos valores morais e éticos, da ordem, da disciplina, responsabilidade, compromisso e ideais. É todo um sistema de valores adquirido através dos relacionamentos com os pais, família e sociedade.

Assim, vemos que, se a atividade física tem papel importante no desenvolvimento do Ego, o esporte, enquanto atividade competitiva, também vai interferir profundamente na estruturação do Superego.

Isso torna-se mais evidente na adolescência, uma época de crise. Nessa fase há, pelo lado dos instintos, aumento dos

Endereço para correspondência:

Dra. Eronides Borges da Fonseca

Av. Atlântica, 514/1.207

22010-000 (Leme) - Rio de Janeiro, RJ impulsos agressivos e amorosos (sexuais), da força e da capacidade de exercer estes impulsos. As mudanças são súbitas no corpo e na mente, obrigando o Ego a empregar defesas para manter o equilíbrio intrapsíquico.

A nova consciência do corpo determina novos sentimentos, novos pensamentos, exigindo nova integração da personalidade. Nesse momento os elementos que entram na dinâmica intrapsíquica são, por um lado, as forças e exigências dos impulsos agressivos e sexuais (Id), a parte mediadora e executiva da personalidade (Ego) e, por último, o sistema de valores ou consciência, os conceitos de certo e errado, os imperativos morais e ideais (Superego). Do interjogo dessas três instâncias dependerá o equilíbrio intrapsíquico.

Quando essa interação é harmoniosa e equilibrada, não é percebida. São as falhas que mostram o processo, exatamente como acontece com os batimentos cardíacos ou a respiração. Essa crise adquire muitas vezes a forma de verdadeira guerra (adolescência patológica) se o Ego não pode contar com a ajuda do Superego para manter o equilíbrio intrapsíquico. São distúrbios de conduta ou, nos casos mais graves, doença psicossomática, delinqüência, drogadição ou doença mental.

A estruturação de um Superego nem tão permissivo nem tão rígido ajuda o Ego a lidar com os impulsos agressivos e os amorosos de forma construtiva, segundo padrões aceitos pela sociedade, sem gerar culpa. O Ego fica livre para a percepção da realidade externa, favorecendo os processos de aprendizagem e socialização. Por outro lado, a atividade esportiva proporciona o agrupamento sadio, facilitando novas identificações que possibilitam ao adolescente crescimento e reestruturações mentais.

$\mathrm{O}$ aumento da independência dos pais produz um vazio interno. $\mathrm{O}$ apego a um ideal ajuda a preenchê-lo. O idealismo é a característica dessa fase e dos jovens de modo geral. O ideal não é contaminado pelos impulsos agressivos ou sexuais, não conduzindo à prática de atos proibidos, nem à culpa.

Por todas essas razões, a atividade esportiva na adolescência é de vital importância. A disciplina, a responsabilidade, os ideais e os valores éticos que são a essência do esporte, associados às atividades em grupo tão necessárias e procura- 
das pelo adolescente, fazem do esporte, mais do que atividade física ou de lazer, uma conduta terapêutica.

Na nova estruturação da personalidade, a criação de um Ego com defesas variadas e adequadas e de um Superego com valores éticos, morais, responsável mas tolerante, é de capital importância para a saúde mental.

Considerando que o acesso ao mundo instintivo através do preenchimento de necessidades básicas, tais como saúde, alimentação, família, escola, etc., não cobre a extensão nem a variedade de necessidades instintivas individuais, o caminho é fornecer ao próprio indivíduo os meios para que possa gerir esse mundo instintivo de forma saudável, prazerosa e construtiva.
O uso do Esporte como meio de crescimento do Ego e de estruturação sadia do Superego preenche tais fins. Achamos, portanto, que as práticas esportivas, sejam de forma lúdica na infância, sejam de forma competitiva na adolescência, são fatores para o desenvolvimento e para a saúde mental.

Consideramos que a estabilidade emocional desempenha um papel fundamental para que as pressões familiares, econômicas e sociais possam ser suportadas.

Este enfoque sobre a atividade esportiva permite ação profilática para evitar as evasões escolares, o uso das drogas e a violência. Isso inclui o entendimento dessas questões na preparação dos profissionais que lidam com tais atividades. 